\title{
Expression of cecropin B in Pichia pastoris and its bioactivity in vitro
}

\author{
XIUQING WANG ${ }^{1}$, MINGXING ZHU ${ }^{2}$, GUIMAO YANG ${ }^{1}$, CHUNXIA SU $^{3}$, \\ AIJUN ZHANG ${ }^{1}$, RUIBING CAO ${ }^{4}$ and PUYAN CHEN ${ }^{4}$ \\ ${ }^{1}$ School of Clinical Laboratory of Medicine; ${ }^{2}$ Laboratory Animal Centre; ${ }^{3}$ School of Basic Medical Science, \\ NingXia Medical University, Yinchuan 750004; ${ }^{4}$ Key Laboratory of Animal Disease Diagnosis and Immunology, \\ Ministry of Agriculture, Nanjing Agricultural University, Nanjing 210095, P.R. China
}

Received April 5, 2011; Accepted May 2, 2011

DOI: $10.3892 /$ etm.2011.262

\begin{abstract}
Natural cecropin B (CB), consisting of 35 amino acids, is a member of the cecropin family with the highest antibacterial activity. Here, a novel approach for the generation of recombinant $\mathrm{CB}$ in the methylotrophic yeast Pichia pastoris was explored. For this purpose, the $\mathrm{CB}$ gene was amplified by recursive PCR (rPCR) and cloned into the pPICZ $\alpha$ A vector. The SacI-linearized plasmid pPICZ $\alpha \mathrm{A}-\mathrm{CB}$ was transformed into $P$. pastoris SMD1168 by electroporation. The expression of recombinant $\mathrm{CB}$ was induced with $1.0 \%$ methanol at $\mathrm{pH} 5.0$ for $60 \mathrm{~h}$ at $28^{\circ} \mathrm{C}$. Recombinant $\mathrm{CB}$ was purified using cationic exchange chromatography; $5.0 \mathrm{mg}$ of pure active CB was obtained from $100 \mathrm{ml}$ of culture broth supernatant. Antimicrobial assays demonstrated that $\mathrm{CB}$ has a broad spectrum of antimicrobial activity against both Grampositive and Gram-negative bacteria. Our results suggest that the $P$. pastoris expression system can be used to produce large quantities of fully functional $\mathrm{CB}$ for both research and industrial purposes.
\end{abstract}

\section{Introduction}

Antimicrobial peptides (AMPs) are amphiphilic, positively charged molecules (1-4) that have emerged as novel antimicrobial agents for use in therapeutics, animal drugs and food preservatives. In recent years, many different types of AMPs have been identified in various organisms, including amphibians, mammals, plants, invertebrates and prokaryotes (1,5-7). Currently, the database of the National Center for Biotechnology Information records more than 800 sequences of antibacterial peptides and proteins from both animals and plants.

Correspondence to: Dr Puyan Chen, Key Laboratory of Animal Disease Diagnosis and Immunology, Ministry of Agriculture, Nanjing Agricultural University, Nanjing 210095, P.R. China

E-mail: puyanchen@yahoo.com.cn

Key words: antibacterial activity, cecropin B, expression, Pichia pastoris, antimicrobial assays
The cecropin family of antibacterial peptides is found in the immune hemolymph of silkworm pupae (8), insects and mammals $(9,10)$ and plays an important role in the innate immune systems of these animals. The cecropin family is comprised of cecropins A, B, C, D, E and F, all of which are 35 to 39 amino acids in length and share highly homologous sequences (11). These peptides were originally described as having a broad spectrum of antibacterial activity against both Gram-positive and Gram-negative bacteria, but lacking the ability to lyse eukaryotic cells (12). Therefore, cecropins are considered to be valuable peptide antibiotics, particularly against bacteria that have developed resistance to chemical antibiotics. Moreover, previous studies (5) have demonstrated that cecropins lyse cancer cells, opening the possibility for their use in medical applications (13).

Over the past decade, bacterial resistance to antibiotics has risen dramatically. Thus, there is an increasing need to discover and introduce novel effective antibiotic drugs. Cationic antimicrobial peptides are one potential source of novel antibiotics. Antimicrobial peptides are naturally occurring antibiotics (14). As part of the innate immune system of vertebrates, these peptides have direct antimicrobial function (15). However, few peptide antibiotics have been tested in clinical trials, and these few have exhibited mixed results (16-19). ABP-CB is a promising novel antibiotic candidate. However, the yield of $\mathrm{ABP}-\mathrm{CB}$ extracted from the silkworm is fairly small. The use of recombinant expression methods may allow for the production of a sufficient quantity of $\mathrm{ABP}-\mathrm{CB}$ in order to meet the demand. We expressed ABP-CB in the methylotrophic yeast Pichia pastoris, which has been widely utilized as a heterologous gene expression system. The increasing popularity of this expression system is attributed to three key advantages: i) it possesses a highly regulated alcohol oxidase (AOX1) promoter gene that can be induced by methanol and repressed by glucose and glyceroland; ii) a minimal salt medium yields a high cell density, making this system cost-effective; and iii) $P$. pastoris possesses subcellular organelles, such as an endoplasmic reticulum and Golgi apparatus, allowing for post-translational modifications that include protein folding, disulfide bridge formation and glycosylation (20-24).

Here, the synthesis of the ABP-CB gene, the extracellular expression of ABP-CB protein in P.pastoris SMD 1168 and 
the characterization of the biological activity of recombinant ABP-CB are described in detail.

\section{Materials and methods}

Materials. E. coli DH5 $\alpha$ was used for cloning the pPICZ $\alpha$ A-ABP-CB plasmid. E. coli K88 and Staphylococcus aureus (Cowan I) were used for the antibacterial assay.

The pPICZ $\alpha$-A vector (Invitrogen) was used for the expression of ABP-CB. The P. pastoris strain SMD1168 (his mut $^{+}$) was used for the expression of the ABP-CB protein.

The restriction enzymes XhoI, XbaI and SacI and T4 DNA ligase were purchased from Takara (Nanjing, China).

Synthesis of cecropin B. Three 60-bp oligomers with 20 bases complementary to their $3^{\prime}$ ends were designed based on the $\mathrm{CB}$ amino acid sequence. In order to express the native $\mathrm{N}$-terminus of $\mathrm{CB}$, a XhoI restriction site was introduced into the $\alpha$-factor secretion signal of the pPICZ-A expression vector to allow in-frame cloning, and a nucleotide sequence encoding the KEX2 cleavage site was placed upstream of the $\mathrm{CB}$ gene. At the C-terminus, an Asn codon, a $X b a I$ restriction site and a stop codon were introduced. The sequences of the primers were as follows: F1, cctctcgagaaaagaaagtggaaggtcttcaagaaga tcgaaaagatgggtcgtaac; F2, gatagctggaccagccttgacgataccgttacg gatgttacgacccatctttc; F3, gctggtccagctatcgetgtcetaggtgaagct aaggctctacaa tga tct aga act.

Gene splicing by overlap extension (SOE) was used for gene synthesis (Fig. 1). An additional pair of primers was designed for identification of the recombinant vector and yeast. The upstream primer targeted the $5^{\prime} \mathrm{AOX}$ gene region of $P$. pastoris, and the downstream primer targeted the insertion region of CB; the amplification length was $496 \mathrm{bp}$. The sequences of the primers were as follows: P1: 5'GTCTCC ACATTGTATGCTTC3'; P2, 5'CTGTGCAGGAACTTGAT3'.

All primers were synthesized by the Shanghai Branch Office of Invitrogen.

PCR amplification was performed according to the SOE method using the F1, F2 and F3 elements as templates and primers. In addition, Touchdown (TD) PCR technology was used to optimize the PCR method in order to ensure the specificity of the SOE synthesis. The TD-PCR reaction involved the following solutions: $5 \mu \mathrm{l} 10 \mathrm{X} \mathrm{Mg}^{2+}$-free PCR buffer; $3 \mu \mathrm{l}$ $25 \mathrm{mmol} / 1 \mathrm{MgCl}_{2} ; 1 \mu \mathrm{l} 10 \mathrm{mmol} / \mathrm{l} \mathrm{dNTP} ; 2 \mu \mathrm{l}$ each $40 \mathrm{pmol} / \mathrm{l}$ F1, F2, F3; $0.5 \mu 1$ Takara ExTaq ${ }^{\mathrm{TM}}$; and $38.5 \mu$ l sterile ultrapure water. All solutions were mixed uniformly and centrifuged for use in TD-PCR. The reaction was initialized at $94^{\circ} \mathrm{C}$ for $2 \mathrm{~min}$ and TD-PCR circulation was performed at $94^{\circ} \mathrm{C}$ for $30 \mathrm{sec}$; the annealing temperature was decreased from 65 to $50^{\circ} \mathrm{C}$ in $0.5^{\circ} \mathrm{C}$ increments $/ \mathrm{min}$ and maintained at $72^{\circ} \mathrm{C}$ for $1 \mathrm{~min}$; the temperature was then maintained at $50^{\circ} \mathrm{C}$ after 30 cycles, and then another 15 cycles were performed at an optimization temperature of $52^{\circ} \mathrm{C}$; extension was performed at $72^{\circ} \mathrm{C}$ for $6 \mathrm{~min}$.

Construction of recombinant expression plasmids. PCR products and pPICZ $\alpha-\mathrm{A}$ vectors were digested with XhoI and $X b a \mathrm{I}$, gel-purified and ligated together. E. coli DH5 $\alpha$ was chemically transformed with the recombinant vectors and then cultured at $37^{\circ} \mathrm{C}$ on low-salt LB supplemented with
$25 \mu \mathrm{g} / \mathrm{ml}$ Zeocin for selection of recombinants. The nucleotide sequence of the recombinant pPICZ $\alpha-\mathrm{A}-\mathrm{CB}$ plasmid was verified by restriction analysis and DNA sequencing in order to ensure $100 \%$ identity with the expected sequence and in-frame orientation. The positive clones were then grown for further DNA transformation.

Transformation and PCR analysis of P. pastoris. Yeast cells were transformed using the Pichia Expression kit. Briefly, $80 \mu 1$ of competent $P$. pastoris SMD1168 cells mixed with $5 \mu \mathrm{g}$ SacI-linearized pPICZ $\alpha-\mathrm{A}-\mathrm{CB}$ were transferred into an ice-cold $0.2-\mathrm{cm}$ electroporation cuvette and incubated in an ice bath for $5 \mathrm{~min}$. Immediately following electroporation at $1.5 \mathrm{kV}, 25 \mu \mathrm{F}, 200 \Omega, 1 \mathrm{ml}$ of ice-cold $1 \mathrm{M}$ sorbitol was added to the cuvette, which was then incubated for $1 \mathrm{~h}$ at $30^{\circ} \mathrm{C}$ without shaking. Aliquots of $200 \mu \mathrm{l}$ were spread on YPDS plates supplemented with $100 \mu \mathrm{g} / \mathrm{ml}$ Zeocin, and the plates were incubated at $30^{\circ} \mathrm{C}$ until colonies appeared. As a negative control, linearized pPICZ $\alpha$-A vector alone was transformed into $P$. pastoris SMD1168 cells.

The transformants bearing the genomic integrants of the pPICZ $\alpha$-A-CB plasmids were identified by genomic PCR using primers P1 and P2. The method of 'boilingfreezing-boiling' was used to prepare the Pichia genomic DNA template. PCR amplification was performed with the following conditions: initial denaturation at $94^{\circ} \mathrm{C}$ for $5 \mathrm{~min}$, followed by 26 cycles at $94^{\circ} \mathrm{C}$ for $1 \mathrm{~min}, 46^{\circ} \mathrm{C}$ for $1 \mathrm{~min}$ and $72^{\circ} \mathrm{C}$ for $1 \mathrm{~min}$, and elongation at $72^{\circ} \mathrm{C}$ for $7 \mathrm{~min}$.

Induction of $A B P-C B$ expression in recombinant $P$. pastoris using the shake-flask method. A single colony of transformants was grown in $5 \mathrm{ml}$ of buffered glycerol-complex medium [BMGY, 1\% (w/v) yeast extract, 2\% (w/v) peptone, $1.34 \%$ YNB, $1 \%$ glycerol, $0.4 \mu \mathrm{g} / \mathrm{ml}$ biotin, buffered with $1 / 10$ volume potassium phosphate buffer $\mathrm{pH} 6.0$ ] in a $50-\mathrm{ml}$ flask. The culture was grown at $28^{\circ} \mathrm{C}$ in a rotating shaker at $230 \mathrm{rpm}$ for $24 \mathrm{~h}$ until the culture reached an $\mathrm{OD}_{600}$ equal to 5 . The culture was harvested after centrifugation at $1,500 \mathrm{~g}$ for $5 \mathrm{~min}$ at room temperature. To induce ABP-CB expression, the pellet was resuspended in $25 \mathrm{ml}$ of buffered methanol-complex medium [BMMY, 1\% (w/v) yeast extract, $2 \%$ (w/v) peptone, $1.34 \%$ YNB, $0.5 \%$ methanol, $0.4 \mu \mathrm{g} /$ $\mathrm{ml}$ biotin, buffered with $1 / 10$ volume potassium phosphate buffer $\mathrm{pH}$ 6.0] in a 250-ml flask and grown at $28^{\circ} \mathrm{C}$ with shaking. To maintain expression of ABP-CB, methanol was added to the culture at a final concentration of $1 \%$. In addition, aliquots were sampled throughout the incubation time in order to perform activity assays. Several parameters that could influence the level of protein expression were analyzed. Antibacterial activity assays were performed by measuring zones of growth inhibition of E. coli K88 in thin agar plates, as described by Cipakova et al (25) A total of $100 \mu \mathrm{l}$ of each condensed expression supernatant was added to the wells.

Determination of $A B P-C B$ expression efficiency and protein concentration. The efficiency of ABP-CB expression was assessed by Tricine-SDS-PAGE. Protein concentration was determined using the Bio-Rad dye agent with bovine serum albumin (BSA) as a standard (23). 


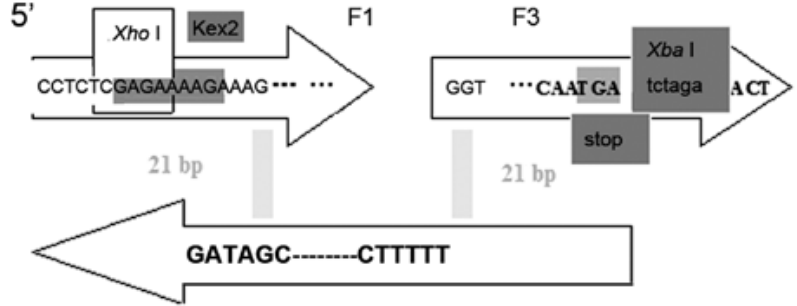

3'

F2

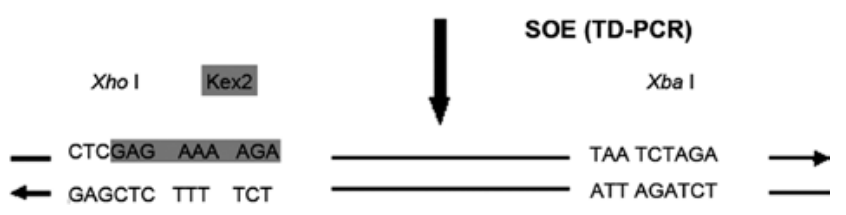

Figure 1. Schematic representation of synthetic cecropin B.

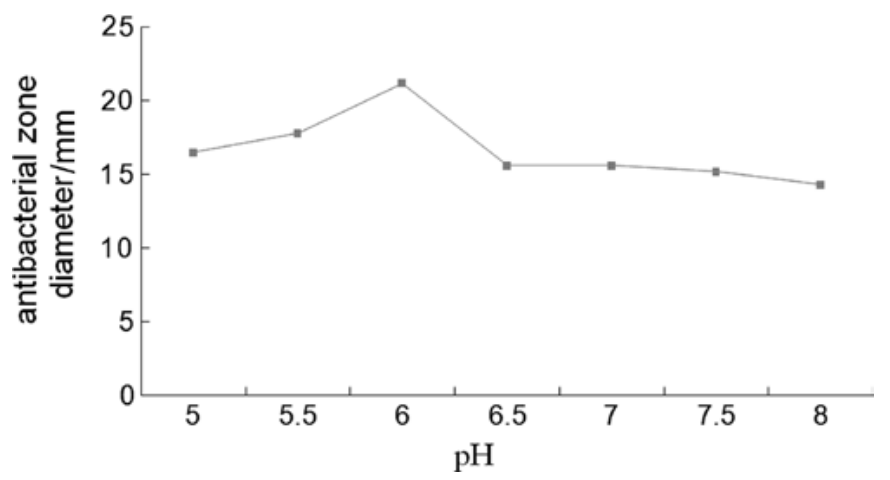

Figure 2. Effect of $\mathrm{pH}$ on the production of recombinant cecropin $\mathrm{B}$.

Purification of secreted cecropin B. After $60 \mathrm{~h}$ of culture, the culture medium $(100 \mathrm{ml})$ was collected by centrifugation at $12,000 \mathrm{~g}$ for $30 \mathrm{~min}$. The supernatant was filtrated using the Amicon ultrafiltration device. The filtrate, which contained proteins that ranged from 3 to $10 \mathrm{kDa}$ in size, was dialyzed overnight in $0.1 \mathrm{M}$ sodium acetate and then applied to a CM-Sepharose CL-6B column (Pharmacia Biosciences, USA) pre-equilibrated with $0.1 \mathrm{M}$ sodium acetate $(\mathrm{pH} 4.5)$. The column was washed with $0.1 \mathrm{M}$ acetate buffer, and the proteins were eluted using a linear gradient of 0.1-1.0 M sodium acetate ( $\mathrm{pH} 4.5)$. The purified proteins were analyzed by Tricine-SDS-PAGE.

Antimicrobial assays. The antimicrobial activity of CB was tested against several Gram-positive and Gram-negative bacteria. The minimal growth inhibition concentration (MIC), which is defined as the lowest concentration of a peptide that can inhibit the growth of a microorganism (26), was determined by performing a liquid growth inhibition assay (27). A stock solution of CB was serially diluted 10 -fold in $0.01 \%$ acetic acid and $0.2 \%$ BSA. Aliquots of each dilution (10 $\mu \mathrm{l})$ were distributed into the wells of a 96-well polypropylene microtiter plate, and each well was inoculated with $100 \mu \mathrm{l}$ of a suspension of mid-log bacteria $\left(2-7 \times 10^{5} \mathrm{CFU} / \mathrm{ml}\right)$ in LB broth Cultures were grown for $24 \mathrm{~h}$ at $30^{\circ} \mathrm{C}$ with vigorous shaking, and the bacterial concentration was evaluated by measuring the absorbance of the cultures at $600 \mathrm{~nm}$ using a microplate reader (Bio-Rad, USA).

Acid stability analysis of recombinant $C B$. Buffers of $\mathrm{pH}$ ranging from 2.5 to 8.5 were prepared. Antibacterial CB peptide $(20 \mu \mathrm{l})$ and of the different buffers were mixed in order to check the acid stability of CB. Buffer alone was used as a negative control.

Heat stability of recombinant $C B$. Recombinant $\mathrm{CB}$ was heated at 60,80 and $100^{\circ} \mathrm{C}$ for $5 \mathrm{~min}$, and then centrifuged at $12,000 \mathrm{rpm}$ for $10 \mathrm{~min}$ in order to separate the precipitate. The supernatant was then used in the antibacterial assays.

\section{Results}

Construction and transformation of $p P I C Z \alpha-A-C B$. Fig. 1 shows a schematic representation of the sequence of the synthetic CB peptide. The amplification of the CB gene was achieved through TD-PCR, resulting in a product of $129 \mathrm{bp}$ in length. After transformation, transformants were screened by restriction enzyme analysis using $\mathrm{XhoI}$ and $\mathrm{XbaI}$ and sequencing. The results of restriction enzyme analysis and DNA sequencing revealed that the $\mathrm{CB}$ gene was inserted correctly into the expression vector. Transformation with the SacI-linearized version of pPICZ $\alpha$-A-CB favored its insertion into the yeast genome by homologous recombination.

Determination of the optimal conditions for secretion of recombinant $C B$. The activity of the recombinant $\mathrm{CB}$ secreted by $P$. pastoris was analyzed under several different conditions. The supernatant was collected and its antimicrobial activity was monitored by performing bacterial inhibition assays. In addition, several parameters that affect the level of protein expression were assayed. The secretion of proteases into the medium, and possibly their release due to cell lysis, is a significant problem in many high-cell-density cultures because it can lead to proteolytic degradation. The induction temperature is also an important parameter. In P. pastoris, incubation at $30,25,20$ and $15^{\circ} \mathrm{C}$ was performed in attempts to minimize extracellular proteolysis. Lower temperatures have been shown to reduce protease levels and to greatly enhance the yield of biologically active proteins in $P$. pastoris $(8,28-31)$. We found that reducing the incubation temperature from 30 to $20^{\circ} \mathrm{C}$ during the methanol-feed phase dramatically increased the yield of recombinant protein (data not shown). Culture of $P$. pastoris on BMMY medium at $\mathrm{pH}$ 6.0 provided the most optimal conditions for the expression of $\mathrm{CB}$, and a methanol induction time of $60 \mathrm{~h}$ was the most suitable (Figs. 2 and 3).

Expression of $C B$ in P. pastoris. The highest CB-producing $P$. pastoris clone was selected for subsequent large-scale protein expression under the most optimal conditions of $28^{\circ} \mathrm{C}$ with $1.0 \%$ methanol for $60 \mathrm{~h}$. Approximately $50 \mathrm{mg}$ of ABP-CB was secreted into 11 of medium. The resultant protein appeared as a single homogeneous band on a Coomassie blue-stained Tricine-SDS-PAGE gel (Fig. 4). The size of the recombinant $\mathrm{CB}$ was consistent with the expected 


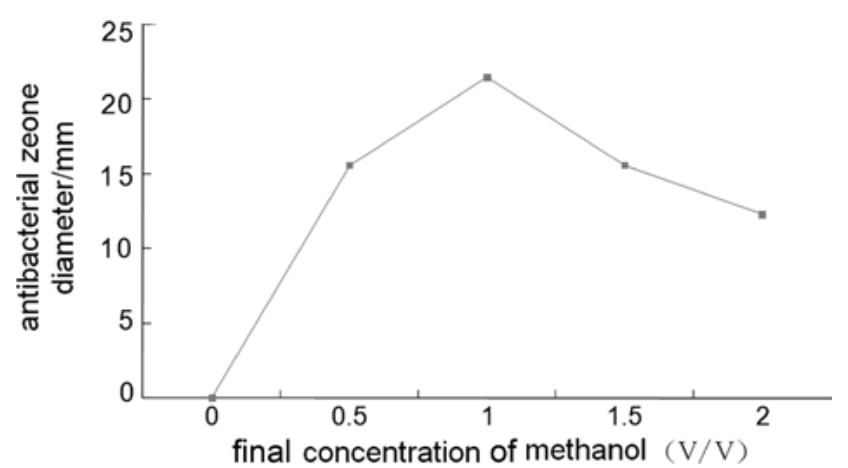

Figure 3. Effect of methanol concentration on the production of recombinant cecropin B.

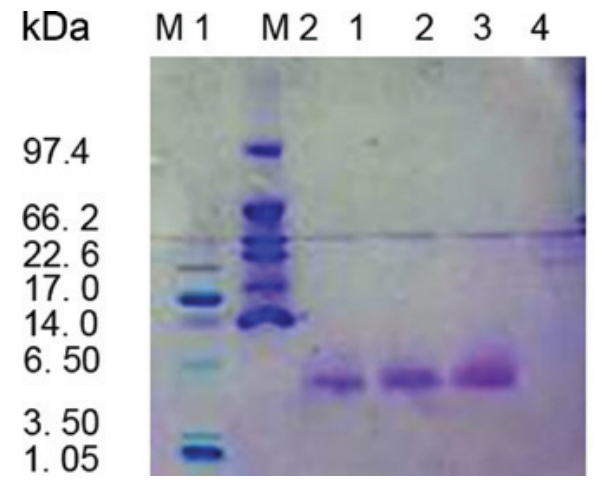

Figure 4. Tricine-SDS-PAGE analysis of cecropin B. M1, ultra-low molecular weight protein marker; M2, low molecular weight protein marker; lanes 1 and 2, culture supernatant of SMD1168/pPICZ $\alpha-\mathrm{CB}$; lane 3, purified cecropin B; lane 4, supernatant of SMD1168/pPICZ $\alpha$.

molecular weight of $4.7 \mathrm{kDa}$ calculated from the amino acid sequence.

Antimicrobial assay. The antibacterial activity of recombinant $\mathrm{CB}$ was qualitatively determined with a radial diffusion assay using $E$. coli as a representative Gram-negative bacterium. $\mathrm{CB}$ was found to be highly effective against $E$. coli (Fig. 5). Similar results were obtained from radial diffusion assays using the Gram-positive bacterium S. aureus (Fig. 6, Table I).

Acid stability of recombinant $C B$. Recombinant $\mathrm{CB}$ had the strongest antibacterial activity at $\mathrm{pH}$ 4.0. There were no obvious changes observed in the diameters of the antibacterial zone at $\mathrm{pH}$ values between 3.5 and 7.5. The diameter of the antibacterial zone decreased gradually at $\mathrm{pH}$ values $>7.5$. Recombinant $\mathrm{CB}$ was stable at low (3.5) and high $\mathrm{pH}$ (8.5), resulting in suppressed antibacterial activity (Fig. 7).

Heat stability of recombinant $C B$. Incubation of the $\mathrm{CB}$ supernatant at $60^{\circ} \mathrm{C}$ for $5 \mathrm{~min}$ had no effect on its antibacterial activity. We found that there were many ingredients in the supernatant of the CB peptide, which were removed by treatment at high temperature. Boiling the supernatant for $30 \mathrm{~min}$ removed approximately $60 \%$ of the mixed proteins found in the supernatant without changing the heat resistance of $\mathrm{CB}$ (Fig. 8).

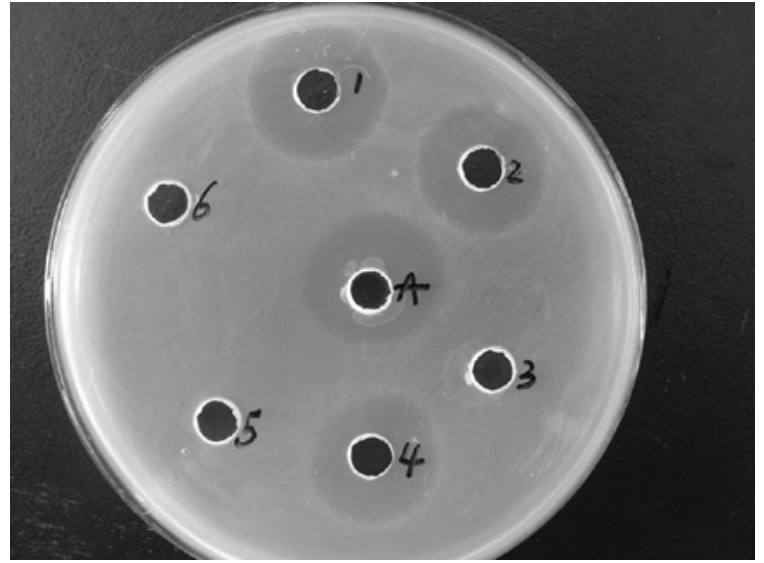

Figure 5. Analysis of the antibacterial activity of cecropin B against $E$. coli. A, Amp control $(25 \mu \mathrm{g} / \mathrm{ml}) ; 1,3$ and 4: supernatant of cecropin B; 2,5 and 6 : control supernatant from P. pastoris SMD1168/pPICZ $\alpha$-A.

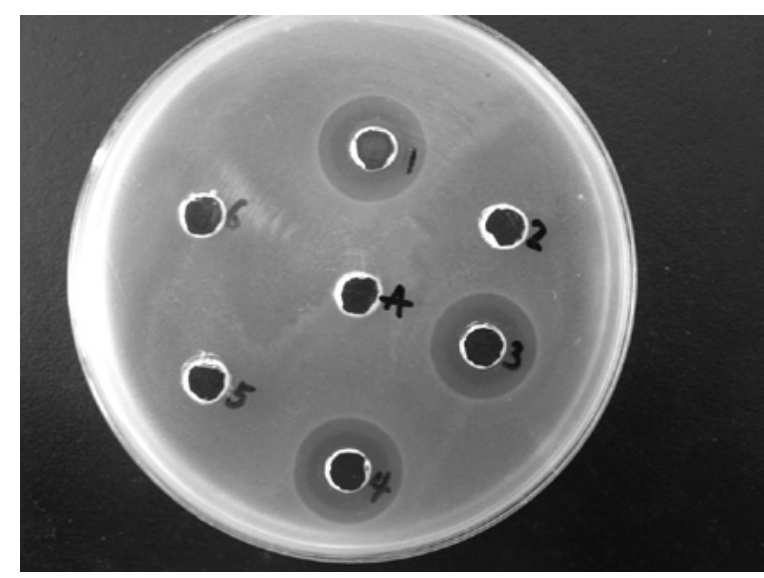

Figure 6. Analysis of the antibacterial activity of cecropin B against S. aureus. A, Amp control ( $25 \mu \mathrm{g} / \mathrm{ml}) ; 1,2$ and 4: supernatant of cecropin B; 3, 5 and 6: control supernatant from P. pastoris SMD1168/pPICZ $\alpha-\mathrm{A}$.

Table I. Antibacterial activity of cecropin B (MIC) expressed as the final concentration in $\mu \mathrm{M}$.

\begin{tabular}{lc}
\hline Microorganism & MIC $(\mu \mathrm{M})$ \\
\hline Gram-positive bacteria & \\
Staphylococcus aureus & 0.89 \\
Bacillus subtilis & 0.98 \\
Sporosarcina & 0.88 \\
Curtobacterium & 0.97 \\
Gram-negative bacteria & \\
E. coli & 0.50 \\
Salmonella pullorum & 0.78 \\
Pseudomonas aeruginosa & 0.98 \\
\hline
\end{tabular}

\section{Discussion}

Cecropins are a family of small basic polypeptides that are mainly present in the hemolymph of insects (30). CB exhibits significant antibacterial activity against Gram-positive and Gram-negative bacteria, and also has potent antitumor activity 


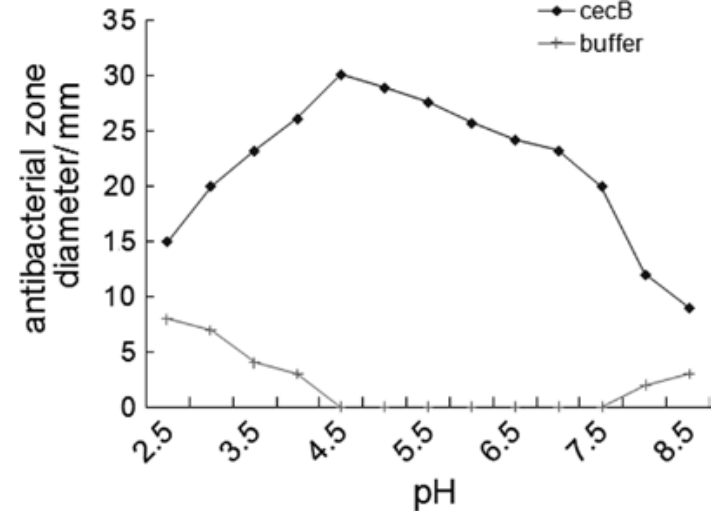

Figure 7. Effect of $\mathrm{pH}$ on the antibacterial activity of cecropin B.

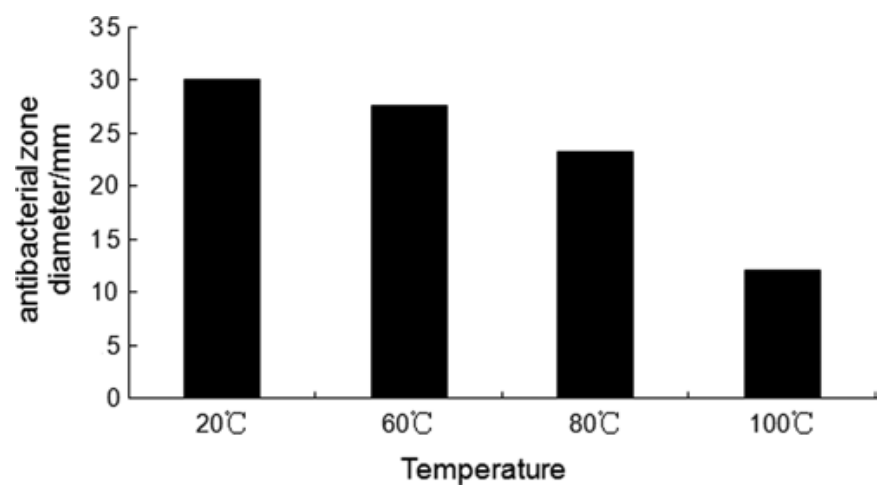

Figure 8. Effect of temperature on the antibacterial activity of cecropin B.

against certain transformed tumor cells, but rather than the hemolytic effect on human erythrocytes. To date, potent CB analogues have been synthesized and have been proven to exhibit effective antibacterial activity; however, heterologous expression of recombinant cecropin has seldom been reported $(32,33)$. Heterologous expression of recombinant proteins results in toxicity for the host cells (27). For a peptide to be used as an antibiotic, the fusion protein partner must be removed from the bacterial expression system; this process is expensive and laborious. Therefore, in the present study, the methylotrophic yeast $P$. pastoris was used as a host for high level expression and secretion of recombinant $\mathrm{CB}$. Recombinant $\mathrm{CB}$ was successfully secreted by $P$. pastoris into the culture supernatant, and $5.0 \mathrm{mg}$ of recombinant $\mathrm{CB}$ was obtained from $100 \mathrm{ml}$ of crude extract. The large-scale production of antibiotic peptides, such as cecropin, will require further exploration regarding the manufacturing methods.

Previously, it was reported that the recombinant protein Psd1, which originates from the C-terminus of the $\alpha$-factor secretion signal of $S$. cerevisiae and contains four additional amino acids (EAEA) at the N-terminal region, was produced by $P$. pastoris. In addition, recombinant Psd1 was shown to decrease antifungal activity against $A$. niger by at least 10 -fold $(22,34)$. In the present study, we cloned the gene encoding CB, with only the KEX2 cleavage site, by recursive PCR in order to obtain CB protein with its native N-terminus. Tricine-SDSPAGE revealed that $\mathrm{CB}$ was successfully secreted by the $P$. pastoris $\alpha$-mating factor signal sequence into the culture supernatant. Activity assays demonstrated that CB had low MIC against all Gram-negative and Gram-positive bacteria tested. Additionally, our results showed that the signal peptide was efficiently processed by the KEX2 protease through the P. pastoris secretory pathway.

Expression of a foreign gene, in this case $\mathrm{CB}$, in P. pastoris and secretion of the active antibacterial peptide suggest that the $\mathrm{CB}$ gene could be introduced into animal cells in order to enhance their resistance to bacterial pathogens. Previously, we showed that both $\mathrm{CB}$ and cecropin $\mathrm{P} 1$ produced by transgene constructs under the control of the cytomegalovirus (CMV) promoter in Chinook salmon embryo cells (CHSE-214) exhibited bactericidal activity against three pathogens (35). In addition, the expression of cecropin in yeast and fish cells demonstrates that the cecropin gene can be introduced into animal cells. Moreover, the expression of $\mathrm{CB}$ by transgenic plants has also been reported $(36,37)$. However, further studies are required to address the feasibility of generating cecropinexpressing transgenic animals for the purpose of increasing their resistance to microbial diseases. In this study, we showed that heterologous CB can be expressed in P. pastoris under the promoter for the secretion signal of the yeast-mating factor. Recombinant CB was expressed at a concentration of $50 \mathrm{mg} / \mathrm{l}$ in culture medium, and it exhibited strong antimicrobial activity. Our results show that $P$. pastoris is a robust system that can be used for the expression of secreted $\mathrm{CB}$, which exhibits antibacterial activity against both Gram-positive and Gram-negative bacteria (7-11).

\section{References}

1. Devine DA and Hancock RE: Cationic peptides: distribution and mechanisms of resistance. Curr Pharm Des 8: 703-714, 2002.

2. Ganz T: Defensins: antimicrobial peptides of innate immunity. Nat Rev Immunol 3: 710-720, 2003.

3. Segrest JP, De Loof H, Dohlman JG, Brouillette CG and Anantharamaiah GM: Amphipathic helix motif: classes and properties. Proteins 8: 103-117, 1990.

4. Zasloff M: Antimicrobial peptides of multicellular organisms. Nature 415: 389-395, 2002.

5. Boman HG: Peptide antibiotics and their role in innate immunity. Annu Rev Immunol 13: 61-92, 1995.

6. Noga EJ and Silphaduang U: Piscidins: a novel family of peptide antibiotics from fish. Drug News Perspect 16: 87-92, 2003.

7. Steiner H, Hultmark D, Engstrom A, Bennich $\mathrm{H}$ and Boman HG: Sequence and specificity of two antibacterial proteins involved in insect immunity. Nature 292: 246-248, 1981.

8. Boman HG and Hultmark D: Cell-free immunity in insects. Annu Rev Microbiol 41: 103-126, 1987.

9. Lee JY, Boman A, Sun CX, Andersson M, Jornvall H, Mutt V and Boman HG: Antibacterial peptides from pig intestine: isolation of a mammalian cecropin. Proc Natl Acad Sci USA 86: 9159-9162, 1989.

10. Hultmark D, Engstrom A, Bennich H, Kapur R and Boman HG: Insect immunity: isolation and structure of cecropin D and four minor antibacterial components from Cecropia pupae. Eur $\mathrm{J}$ Biochem 127: 207-217, 1982.

11. Boman HG, Wade D, Boman IA, Wahlin B and Merrifield RB: Antibacterial and antimalarial properties of peptides that are cecropin-melittin hybrids. FEBS Lett 259: 103-106, 1989.

12. Moore AJ, Devine DA and Bibby MC: Preliminary experimental anticancer activity of cecropins. Pept Res 7: 265-269, 1994.

13. Hancock RE and Lehrer R: Cationic peptides: a new source of antibiotics. Trends Biotechnol 16: 82-88, 1998.

14. Hancock RE and Patrzykat A: Clinical development of cationic antimicrobial peptides: from natural to novel antibiotics. Curr Drug Targets Infect Disord 2: 79-83, 2002.

15. Diamond G: Natures antibiotics: the potential of antimicrobial peptides as new drugs. Biologist 48: 209-212, 2001. 
16. Andres E and Dimarcq JL: Cationic antimicrobial peptides: from innate immunity study to drug development. Med Mal Infect 37: 194-199, 2007.

17. Cereghino JL and Cregg JM: Heterologous protein expression in the methylotrophic yeast Pichia pastoris. FEMS Microbiol Rev 24: 45-66, 2000.

18. Sreekrishna K, Brankamp RG, Kropp KE, Blankenship DT, Tsay JT, Smith PL, Wierschke JD, Subramaniam A and Birkenberger LA: Strategies for optimal synthesis and secretion of heterologous proteins in the methylotrophic yeast Pichia pastoris. Gene 190: 55-62, 1997.

19. Cregg JM, Cereghino JL, Shi J and Higgins DR: Recombinant protein expression in Pichia pastoris. Mol Biotechnol 16: 23-52, 2000.

20. Boze H, Celine L, Patrick C, Fabien R, Christine V, Yves C and Guy M: High-level secretory production of recombinant porcine follicle-stimulating hormone by Pichia pastoris. Process Biochem 36: 907-913, 2001.

21. Lee CY, Lee SJ, Jung KH, Katoh S and Lee K: High dissolved oxygen tension enhances heterologous protein expression by recombinant Pichia pastoris. Process Biochem 38: 1147-1154, 2003.

22. Almeida MS, Cabral KS, de Medeiros LN, Valente AP Almeida FC and Kurtenbach E: cDNA cloning and heterologous expression of functional cysteine-rich antifungal protein Psd1 in the yeast Pichia pastoris. Arch Biochem Biophys 395: 199-207, 2001.

23. Ausubel FM, Brent R and Kingston RE: Protocols in molecular biology. Trends Cell Biol 6: 366-367, 1996.

24. Lehrer RI, Rosenman M, Harwig SS, Jackson R and Eisenhauer P: Ultrasensitive assays for endogenous peptides. J Immunol Methods 137: 167-173, 1991.

25. Cipakova I, Hostinova E, Gasperik J and Velebny V: High-level expression and purification of a recombinant hBD-1 fused to LMM protein in Escherichia coli. Protein Expr Purif 37: 207-212,2004.

26. Shi X, Karkut T, Chamankhah M, Alting-Mees M, Hemmingsen SM and Hegedus D: Optimal conditions for the expression of a single-chain antibody (scFv) gene in Pichia pastoris. Protein Express Purif 28: 321-330, 2003.

27. Jahic M, Gustavsson M, Jansen AK, Martinelle $M$ and Enfors SO: Analysis and control of proteolysis of a fusion protein in Pichia pastoris fed-batch processes. J Biotechnol 102: 45-53, 2003 .
28. Li SZ, Xiong F and Lin Q: Low-temperature increases the yield of biologically active herring antifreeze protein in Pichia pastoris. Protein Express Purif 21: 438-445, 2001.

29. Bencurova M, Rendic D, Fabini G, Kopecky EM, Altmann F and Wilson IB: Expression of eukaryotic glycosyltransferases in the yeast Pichia pastoris. Biochimie 85: 413-422, 2003.

30. Skosyrev VS, Kulesskiy EA, Yakhnin AV, Temirov YV and Vinokurov LM: Expression of the recombinant antibacterial peptide sarcotoxin IA in Escherichia coli cells. Protein Expr Purif 28: 350-356, 2003.

31. Aly R, Granot D, Mahler-Slasky Y, Halpern N, Nir D and Galun E: Saccharomyces cerevisiae cells harboring the gene encoding sarcotoxin IA secrete a peptide that is toxic to plant pathogenic bacteria. Protein Expr Purif 16: 120-124, 1999.

32. Yamada K, Nakajima Y and Nator S: Production of recombinant sarcotoxin IA in Bombyx mori cells. Biochem J 272: 633-636, 1990.

33. Rao XC, Li S, Hu JC, Jin XL, Hu XM, Huang JJ, Chen ZJ, Zhu JM and Hu FQ: A novel carrier molecule for high-level expression of peptide antibiotics in Escherichia coli. Protein Expr Purif 36: 11-18, 2004

34. Cabral KM, Almeida MS, Valente AP, Almeida FC and Kurtenbach E: Production of the active antifungal Pisum sativum defensin 1 (Psd1) in Pichia pastoris: overcoming the inefficiency of the STE13 protease. Protein Expr Purif 31: 115-122, 2003.

35. Sarmasik A and Chen TT: Bactericidal activity of cecropin B and cecropin P1 expressed in fish cells (CHSE-214): application in controlling fish bacterial pathogens. Aquaculture 220: 183-194, 2003

36. Sessitsch A, Kan FY and Pfeifer U: Diversity and community structure of culturable Bacillus spp. populations in the rhizospheres of transgenic potatoes expressing the lytic peptide cecropin B. Appl Soil Ecol 22: 149-158, 2003.

37. Sharma A, Sharma R, Imamura M, Yamakawa M and Machii $H$ Transgenic expression of cecropin $B$, an antibacterial peptide from Bombyx mori, confers enhanced resistance to bacterial leaf blight in rice. FEBS Lett 484: 7-11, 2000. 